\title{
Optical characterization on ITO/TiO2/P3HT/Areca Catechu/Au for thin film hybrid solar cell
}

\begin{abstract}
In this research, dye sensitized solar cell is fabricated by a combination of inorganic titanium dioxide nanoparticles sensitized by a locally available natural dye extract from organic Areca Catechu nut. This hybrid solar cells are fabricated accordingly by deposition of ITO/TiO2/P3HT/Areca Catechu/Au by using electrochemical method. The deposition rates of $\mathrm{TiO} 2$ are varied from $0.05,0.07,0.09$ to 0.11 vs- 1 whereas the number of scan of each layers are fixed to 5. The absorption spectra analysis is carried out in the wavelength range 200 to $600 \mathrm{~nm}$, showed a wide and significant absorption spectrum in UV and visible regions. Analysis shows that scan rate affects the electrical conductivity of hybrid solar cell. The highest conductivity is recorded at $0.278 \mathrm{Scm}-1$ corresponding to the scan rate of $0.07 \mathrm{Vs}-1$ at a potential value of $3.5 \mathrm{~V}$.
\end{abstract}

Keyword: Areca Catechu; Hybrid solar cells; Poly (3-hexylthiophene); Titania nanocrystals $\mathrm{TiO} 2$ 